\section{D) Check for updates}

Cite this: J. Anal. At. Spectrom., 2019, 34,2341

DOI: 10.1039/c9ja90056j

www.rsc.org/jaas

\title{
Correction: The contribution of chemical vapor generation coupled with atomic or mass spectrometry to the comprehension of the chemistry of aqueous boranes
}

Alessandro D'Ulivo*

Correction for 'The contribution of chemical vapor generation coupled with atomic or mass spectrometry to the comprehension of the chemistry of aqueous boranes' by Alessandro D'Ulivo et al., J. Anal. At. Spectrom., 2019, 34, 823-847.

The author regrets that the formula of species $\mathbf{6 b}$ was given incorrectly in Chart 1 of the original article. The correct formula for species $6 \mathbf{b}$ should be $\left[\left(\mathrm{Me}_{2} \mathrm{NH}\right)_{2} \mathrm{BH}_{2}\right]^{+}$, and the correct version of Chart 1 is shown below.<smiles>[R]N[B]BN[R]</smiles>

12

$$
\left[\left(\mathrm{Me}_{2} \mathrm{NH}\right)_{2} \mathrm{BH}_{2}\right]^{+}
$$

\section{$6 \mathbf{b}$}

Chart 1 Intermediate products identified during the hydrolysis of ${ }^{t} \mathrm{BuNH}_{2} \mathrm{BH}_{3}$ (intermediate 12) and $\mathrm{Me}_{2} \mathrm{NHBH}_{3}$ (intermediate $6 \mathrm{~b}$ ) in strongly acidic conditions. ${ }^{57}$

The Royal Society of Chemistry apologises for these errors and any consequent inconvenience to authors and readers. 